\title{
A review of Cocoa Research Institute of Ghana extension activities and the management of cocoa pests and diseases in Ghana
}

\author{
Francis Baah* and Vincent Anchirinah
}

\author{
Cocoa Research Institute of Ghana, P.O. Box 8, Tafo - Akim, Ghana \\ *[Corresponding Author, email: achamfour1966@gmail.com]
}

\begin{abstract}
Extension as an activity is traditionally viewed as a means of transmitting knowledge to farmers by extension institutions. Extension activities are not the preserve of extension institutions alone. Research institutions, input distributors, produce buying agencies, non-governmental organisations and even individuals carry out extension activities in the cocoa sector in Ghana. Blackpod disease caused by Phytophthora palmivora and Phytophthora megakarya, Cocoa Swollen Shoot Virus (CSSV) disease and mirids (capsids) are major constraints facing farmers and much extension efforts are directed at their management The Cocoa Research Institute of Ghana (CRIG), though primarily concerned with the development of sustainable cocoa production technologies, has stepped up its extension activities in recent times to meet the information needs of farmers. Some of these activities have included farmer educational campaigns on farmers' farms and on radio, the use of farmer field schools, active involvement in government control of cocoa pest and disease programme, introduction of the cocoa farmer' newspaper, onfarm studies and several socio-economic surveys. This paper reviews these activities suggesting ways of improvement and concludes that CRIG's leadership role in integrating her activities into the wider cocoa knowledge and information systems is laudable and commendable.
\end{abstract}

Keywords: Cocoa research, Ghana, extension activities

\section{INTRODUCTION}

Cocoa is one of Ghana's major export commodities contributing $26.3 \%$ of export revenue and $26 \%$ of agricultural growth in 2006. The subsector also grew quite significantly at $6.5 \%$ in 2007 compared to only $2.0 \%$ in 2006 (ISSER, 2008). From 2002, cocoa output has followed a general upward trend and it has been suggested that this is a result of higher producer prices, partial liberalization of internal marketing, establishment of a price stabilization system, government - backed rehabilitation programmes, control of pests and disease programmes, fertilizer credits and the privatization of input supply to farmers (International Cocoa Organisation, 2007). The cocoa industry in Ghana is however, afflicted by two major plant diseases and one major group of insect pests. The diseases are Cocoa Swollen Shoot Virus Disease (CSSVD) and the Black pod disease. The major pests of cocoa are the mirids, Distantiella theobroma and Sahlbergella singularis. The economic importance of these diseases and pests are derived from their adverse effects on per hectare yields and consequent losses to the industry's aggregate cocoa output (Asante 1995).
Extension as an activity is not the preserve of extension organizations. Research institutes including CRIG have responsibility to not only develop technologies for clientele, but also share information and knowledge about the technologies with them in an interactive manner. In order to reduce production losses resulting from the effects of these diseases and pests infestation, various control measures have been developed and recommended by CRIG to farmers. The objective of this paper is to evaluate the extent to which CRIG's extension activities have impacted on the management of the major pests and diseases. The review focuses on the various platforms and communication channels that CRIG has employed in the last decade to reach farmers and other stakeholders in the cocoa sector

\section{ECONOMIC LOSSES AND MANAGEMENT OF} THE MAJOR COCOA PESTS AND DISEASES

\section{Blackpod disease}

The black pod is a fungal disease caused by two Phythophthora species, $P$. palmivora and $P$. megakarya. Prior to the occurrence of the $P$. palmivora in 1985, evidence from field studies indicated that losses due to P. palmivora infection 
ranged from 16 to 23\% (Newall, 1969), although loses as high as 38\% were reported (Asare-Nyako, 1974). Losses through P. megakarya infection is however much more drastic with $70-90 \%$ losses or $100 \%$ in some cases.

It has been found that the ability of the black pod fungus to infect and destroy healthy pods is hindered by good aeration in the farm. Therefore, cultural practices aimed at reducing humidity and improving aeration help to prevent the fungus from establishing and spreading. Chemical control involves the coating of pod surface with recommended fungicides which stops the germination of fungal spores (Opoku et al, 2007). Spraying of cocoa farms against black pod begins in the rainy season at 3-4 weekly intervals or at any time a farmer spots 1-2 infected pods (CRIG, 2008). Current research efforts are towards the possible use of phosphonic acid, a fully systematic fungicide for the control of $P$. megakarya (Opoku and Owusu, 1995) and the breeding of resistant planting materials

Cocoa Swollen Shoot Virus Disease: Cocoa swollen shoot disease (CSSVD) is caused by a virus which is transmitted by a mealy bug. It was originally discovered in Ghana in 1936. The disease is also present in other West African producing countries, Nigeria, Cote d'Ivoire, Sierra Leone and Togo. The cocoa swollen shoot disease is undoubtedly the single most important threat to the Ghanaian cocoa industry. It is largely responsible for Ghana's loss of her position as the world's leading cocoa producer (Thresh and Owusu, 1986). The loss to the State in terms of cocoa revenue is immeasurable; and so is the loss of income to farmers. The economic importance of the CSSVD lies in its debilitating and destructive effect on the cocoa tree sometimes within as short a period as three years (Ollennu et al 1989). The basic method of controlling vector-borne viruses of tree crops is by eradicating sources of infection. Such measures have been used extensively in Ghana since 1944 in attempt to control or at least contain the spread of the swollen shoot disease. The cutting out of infected trees is usually preceded by surveys in which infected trees are identified by spotters and the farm marked out (Thresh and Owusu, 1986).

Capsids: Capsids are the most important pests of economic significance to cocoa in Ghana. The two main species responsible for crop losses are Sahlbergella singularis and Distantiela theobroma. These insects are capable of reducing yields of healthy farms to less than $25 \%$ of their potential in one year (Wills, 1962). Seedlings may completely fail to become established due to presence of capsids. Even when seedlings are not killed outright, capsids delay cocoa coming into bearing several years. On national scale, Owusu Manu (1984) that about 25\% of acreage under cocoa was badly affected by capsids causing annual losses of about 100, 000 tons of dry cocoa at the time.

\section{EXTENSION SYSTEMS}

Extension as a component of agricultural information system: Information and access to it are increasingly being regarded as important resources especially in third world agriculture. Access to information is more crucial and lack of it more critical in agriculture than in other areas of human endeavour (Baah, 2009; ISNAR, 1991). The term 'extension' is said to have emerged from educational developments in mid-nineteenth century England. Agricultural extension conveys the idea of farmers being taught how to use a new technology or manage their farms well. The educational theme or function of extension has been recognised since its evolution probably as old as the beginning of permanent agriculture (Jones and Garforth, 1997).

The educational functions of extension are perceived in terms of some key activities. These activities include the transfer of messages through direct contact between extension agents and farmers or indirect contact involving intermediaries and provision of feedback to researchers on farmers' reactions to new technology to refine future research agenda. It also involves the development of linkages with researchers, government planners, NGOs, farmers' organisations, banks, and the private commercial sector and the monitoring of the extension system, and evaluation of its performance at farm level (Farrington, 1994). Information 'transmitted' through agricultural extension can be classified into two broad categories: Pure or general agricultural information designed to improve existing cultural and production practices and farm management and agricultural information tied to new physical inventions such as machinery, chemicals, veterinary services, pharmaceuticals, soil tests results and computer programmes to facilitate farm operations (Umali and Schwartz, 1994).

Besides the information dissemination function, a major function of agricultural extension services especially in the developing countries is the provision of a framework for the development of government policies for rural development with the twin goals of 
producing cheap food for the population and poverty reduction. Poverty reduction strategies adopted by many governments in the past have included the encouragement of labour intensive technologies to facilitate employment of the landless and the development of alternative livelihoods for the poor (Garforth and Harford, 1995).

Cocoa extension in retrospect: Agricultural extension like other social sectors such as education and health has been experiencing rapid changes both in the developing and the developed world, in the ways in which agricultural extension is funded and how its services are delivered. In Ghana, prior to the year 2000, cocoa extension was undertaken by the cocoa services division (CSD) a subsidiary of the COCOBOD. The primary aim of CSD was to provide an advisory function for improved cultivation of cocoa, and to achieve this, it employed a modified form of Training and Visit (T\&V) system using extension methods such as demonstrations, rallies, face to face contact with farmers and provision of inputs (the input supply functions were later dropped following privatization) (MASDAR, 1998). Cocoa extension became the responsibility of the State, managed by the Agricultural Extension Services of the Ministry of Food and Agriculture (MOFA) in 2002. According to Amezah and Hesse (2002), the impact of this change has been that, cocoa did not get the same attention under MOFA as it received under COCOBOD because of poorer extension coverage and budgetary constraints. It was largely expected during the process of transferring cocoa extension to MOFA that the levy on cocoa sales which funded CSD would be transferred to MOFA to fund cocoa extension there. This has not happened and the present state of extension support to cocoa farmers is far from satisfactory (Osei-Bonsu, Baah and Afrifa, 2001), prompting calls for the involvement of other agencies such as the licensed buying companies, the farmers' organisations and even CRIG to provide extension service support to cocoa farmers (Baah, 2002). Perhaps in response to these calls, MOFA in 2003 published a memorandum in the Ghanaian newspapers inviting the private sector to bid to provide extension services in selected districts similar to arrangements in the livestock sector. Perhaps in response to persistent demand from farmers and other stakeholders for Ghana Cocoa Board to institute an extension system for farmers, the board in early 2009 set up a committee to develop modalities for just that. The proposition is to have cocoa extension within the Cocoa Swollen Shoot Diseases Control Unit, a division of the board. A stakeholders' workshop to collate views on how the new extension system is to operate took place in May 2009 and all appears set for the inauguration of the new extension system. However, the proposals for the new extension system recognise the need for CRIG to continue to provide extension support to farmers.

\section{CRIG EXTENSION ACTIVITIES}

In 1995 the sudden emergence of P. megakarya and its virulence made many farmers in Ghana attribute the severity of the disease to evil forces or the consequence of the creation of the Volta Lake (Opoku and Owusu, 1995). These beliefs militate against efforts to control the disease. The solution lied in education of the cocoa farming population. Pluralism in terms of methods and approaches are the guiding principle towards current efforts by CRIG to meet the information needs of farmers. CRIG launched a farmer educational campaign involving the use of the radio, on-farm engagements with farmers, production and distribution of education materials including posters, leaflets, production guides and flyers. In collaboration with Cadbury Ghana Limited, CRIG also launched a cocoa farmers' newspaper written in simple language to not only inform farmers on the management of cocoa pests and diseases, but to also provide farmers with reference materials on these pests and diseases. How have these efforts fared?

The radio has broad appeal and reaches a large audience quickly (Kenny 2002). The limitation that it was a one-way communication channel has been overcome in Ghana though massive improvement in telecommunication which enables the audience to respond via telephone to radio broadcasts (Baah, 2006). The radio remains the most important medium for communicating with rural populations of developing countries (Odame and Kassam, 2002). The purpose of the radio sensitization activity is to reach to a larger proportion of the cocoa farming populace and other stakeholders simultaneously. Not all farmers have access to all mass media, but many will have access to radio at home. This is very true of most Ghanaian cocoa farmers who regard the radio as a reliable source of information. Not all scientists have the training to communicate effectively with farmers on radio. There must be a review of previous broadcasts to access impact and the outcome built into subsequent programmes. These issues must be addressed if the radio is to be an effective platform for interactive communication with farmers. 
On-farm trials provide a unique platform for researchers to interact with farmers. CRIG has used these trails to validate and evaluate research recommendations with farmers. The outcome of these trials has often led to modification of technologies to suit farmers' socio-economic contexts. Researchers must be trained in how to relate to farmers to ensure effective communication and interaction (Rhoades, 1989). However, the mere use of a farmers' land or other resources in a study directed and controlled by researchers is unlikely to achieve the desired result of building partnership between scientists and farmers. Scientists or researchers must regard on-farm trials as another platform for them to learn from farmers of their problems and concerns and incorporate these into the development of sustainable solutions. To be effective, CRIG on-farm studies must be properly planned and coordinated with specified objectives.

In addition to the use of the radio and on-farm trials, CRIG also organises farmer educational rallies (FER) in cocoa communities throughout the cocoa growing regions. Farmer educational rallies have been used by CRIG over the years to exchange knowledge and ideas with cocoa farmers. It has had the advantage of reaching out to large numbers of farmers at a time. In addition, the informal context within which it is held appeal to farmers who 'come out of their shells' as it were to discuss their problems with researchers. The use of posters, leaflets and flyers written in very simple language designed to capture the attention of cocoa farmers and used during these interactions with farmers is commendable. CRIG recently developed separate posters and leaflets with information on blackpod and capsids management, meant to serve as reference materials for farmers. If not managed properly, FER has the tendency to be dominated by a few opinion leaders who may view it as an opportunity to raise themselves in the eye of the community. Like all programmes, it has to be preceded by careful planning to ensure that its objectives are met. In addition, it has to be seen to be a perpetual part of the institute's calendar of activities rather than an occasional thing.

CRIG working in collaboration with Cadbury International Ghana has developed an educational newspaper (called, 'GHANA COCOA FARMERS NEWSPAPER') for cocoa farmers. This paper is written in simple language, structured and arranged clearly, making it stimulating for farmers to read. Sections of this paper are usually devoted entirely to control of cocoa pests and diseases including information on recommended pesticides and its application. Whilst there has been positive feedback on the newspapers, there are bottlenecks that need to be address. These include the limited circulation and the absence of versions in the local languages. In addition, a mechanism must be put in place to involve farmers in determining content for the paper. If these problems are addressed, the farmers' newspaper is an innovative addition to the basket of medium through which research scientists of CRIG and farmers could communicate effectively.

Open days are occasions when research organizations open their gates to people including farmers to visit and see the development of research technologies. They provide the platform for researchers to showcase the latest knowhow on the scientific front. It is a regular feature of the calendar of activities of many research institutes. At CRIG, it has been held regularly. However, on the occasion of the $70^{\text {th }}$ anniversary of its establishment, CRIG organised an open day to highlight its research activities to all stakeholders. It is recommended that open days be held annually and organised such that CRIG can obtain feedback from farmers and other stakeholders on her research activities.

\section{CONCLUSION AND RECOMMENDATIONS}

This paper has provided insights into CRIG extension activities aimed at promoting the effective management of cocoa pests and diseases. It is concluded that it is commendable for a research Institute to consciously develop programmes to interact with farmers and other stakeholders. However, extension activities have to be preceded by detailed planning to ensure that the desired impact has been achieved. CRIG should therefore undertake an impact evaluation of each of the platforms that it has used to interact with farmers. Research activities are only a part of a knowledge and information system. For synergy to be attained, information flows and interactions between all elements in the system are required. The impact of the CRIG extension activities have to be viewed against the extent to which they contribute to the attainment of this synergy. Nevertheless, there is evidence (Baah, Anchirinah and Badu-Yeboah, 2009) that the impact of these activities have been positive on the management of cocoa pests and diseases in Ghana. In a recent survey of pesticides use on cocoa in Ghana (Baah, et al., 2008), farmers spoke of improved management of diseases and pests on their farms linked in part to CRIG extension activities. 


\section{ACKNOWLEDGEMENTS}

The authors are grateful to the editorial board of CRIG for reviewing the paper and offering useful suggestions for improvements. The paper is published by the kind permission of the Executive Director of the Cocoa Research Institute of Ghana.

\section{REFERENCES}

Adu -Ampomah, Y., Owusu, G.K., Sackey S., Padi, B. and Abdul Karim, A. (1996). Use of gamma rays to induce mutants resistant to cocoa swollen shot disease in Theobroma cacao. Planting 115: 72 -76

Amezah, K. and Hesse, J. (2002). Reforms in the Ghanaian Extension System, Agriculture and Rural Development Department, Washington D.C.: The World Bank.

Asante, E.G (1995). The economic relevance of plant diseases and pest management in the Ghana cocoa industry. A paper presented at the international cocoa pests and diseases seminar. Accra, November $6^{\text {th }}-$ $10^{\text {th }}$. Tafo: CRIG

Asare - Nyarko A. (1974). Towards an economic chemical control of the blackpod disease of cocoa in Ghana, Ghana Journal of Agricultural Science. 17: 17-23.

Baah, F. (2002). Towards A Pluralistic Approach in Extension Services Delivery to Ghanaian Cocoa Farmers. Journal of the Ghana Science Association, 4(1): 78-82.

Baah, F. (2006). Cocoa cultivation in Ghana: An analysis of farmer' information and knowledge systems and attitudes. PhD thesis, Institute of International Development and Applied Economics, University of Reading .UK.

Baah, F., Opoku, I.Y., Adu-Ampomah, Y., Anchirinah, V., Badu-Yeboah, A., Osei-Sarkodie, Y., Assuah, M., Cudjoe, A.R., Nkansah, A., Boafo, N., Bediako, A., and Adjepong, D. (2008). Final Report: European Cocoa Association / Ghana Cocoa Board Pesticides Study. Tafo: Cocoa Research Institute of Ghana.

Baah, F. Anchirinah, V. and Badu-Yeboah, A. (2009). Perceptions of extension agents on information exchange with cocoa farmers in the Eastern region of Ghana. Scientific Research and Essay, 14

CRIG, (2007). Information Guide. Tafo: Cocoa Research Institute of Ghana (CRIG)

Dakwa, J.T. (1987). A serious outbreak of blackpod disease in a marginal area of Ghana. Proceedings of the $10^{\text {th }}$ international cocoa research conference. Pp 448-451

Farrington, J (1994). Public Sector Agricultural Extension: Is there Life After Structural Adjustment? Natural
Resources Perspectives Number 2. London: Overseas Development Institute (ODI).

Garforth, C. and Harford, N. (1997). Extension Experiences in Natural Resources Management in the 1980s and 1990s. In: Scarborough, V., Killough, S., Johnson, D.A and Farrington, J (eds.), Farmer-led Extension, pp. 2333. London: Overseas Development Institute.

Garforth, C and Harford, N. (1995). Issues in Agricultural Extension: Experiences of Agriculture and Natural Resources Management programmes through the 1980's and 1990's. AERDD, The University of Reading.

CRIG (2008). Guide to the control of Black pod Disease in Ghana. Tafo: Cocoa Research Institute of Ghana (CRIG).

Henderson, C.P, Asante, E.G., Donkor, M.A., Ameyaw, K.O, Luterbacher, M.C., Akrofi, A.Y and Boakye, P.D. (1994). Farmer managed fungicide trials (Volta and Brong Ahafo Regions), Rep Cocoa Research Institute of Ghana. Tafo, Ghana. Pp 70-76

ISSER (2008). The State of the Ghanaian Economy in 2007. Legon: Institute of Statistical Social and Economic Research, University of Ghana.

ISNAR (1991). Review of Ghana Agricultural Research, Vol. 11, Annexes. The Hague; International Service for National Agricultural Research (ISNAR).

Jones, G. E. and Garforth, J. (1997). The History, Development, and Future of Agricultural Extension. In: Swanson, B.E., Bentz, R.P and Sofranko, A.J (eds, 1997). Improving Agricultural Extension: A reference Manual (Chapter1). Rome: FAO.

Kenny, C. (2002). Information and Communication Technologies for direct poverty alleviation: Costs and Benefits. Development Policy Review. 20 (2): 141-157

Odame, H.H and Kassam, A. (2002). Listening to Stakeholders: Agricultural Research and Rural Radio Linkages .ISNAR Briefing Paper 48. the Hague .ISNAR

Ollennu, LAA, Owusu, G.K and Thresh J.M (1989). The control of cocoa swollen shoot disease in Ghana' Crop Protection 5(1): 41-52

Opoku, I.Y and Owusu, K. (1995). A severe type of blackpod disease of cocoa in Ghana. Newsletter 11: 14. Tafo: Cocoa Research Institute of Ghana

Opoku, I.Y, Assuah M.K. and Domfeh, O. (2007). Manual for the identification and control of diseases of cocoa. Technical Bulletin No. 16, Tafo: Cocoa Research Institute of Ghana.

Osei-Bonsu, K., Baah, F. and Afrifa, A. A. (2001). Evaluation of Cocoa Conditions, Problems and Possible Solutions in four Farming Communities surrounding the Kakum Forest Reserve, Central 
Region, Ghana. Consulting Report for Conservation International, Tafo: Cocoa Research Institute of Ghana.

Owusu- Manu, E. (1984) The basis for capsids control in cocoa farms in Ghana (unpublished ). Tafo: Cocoa Research Institute of Ghana.

Rhoades, R. (1989). The Role of Farmers in the Creation of Agricultural Technology. In: Chambers, C., Pacey, A and Thrupp, A.L (eds), Farmer First: Farmer innovation and agricultural research. London: Intermediate Technology Publications.
Thresh, J.M and Owusu, G.K (1986). The control of cocoa swollen shoot disease in Ghana: and evaluation of eradication procedures. Crop protection 5(10) pp 4152

Umali, D. L. and Schwartz, L. (1994). Public and Private Agricultural Extension: Beyond Traditional Frontiers. World Bank Discussion Paper 236. Washington D.C.: The World Bank.

Wills, J. Brian, Ministry of food and Agriculture, Accra, Ghana (1962). Agriculture and land use in Ghana. Oxford University press London. Accra. New York. Pp330 